\title{
Transformation of Career-oriented English Teaching Idea
}

\section{Yu Xiao}

Sichuan College of Architectural Technology, Deyang, Sichuan, 618000, China

\begin{abstract}
With development of education reform, colleges and teachers have paid more and more attention to career-oriented teaching idea. Target and time required of the reform are directed by career. The work analyzed career-oriented English teaching including present situation as well as theoretical basis and methods of idea transformation, thus changing and improving English teaching idea.
\end{abstract}

KEYWORDS: Career-oriented; Teaching Situation; English Teaching

\section{INTRODUCTION}

With development of education reform, people have paid more and more attention to cultivation of communicative ability in English teaching. English learning can lay a foundation for students and foster their abilities to use English. Through English teaching, students can pass the examination and apply English language to communicate, thus improving their job skills. Therefore, teaching idea should be changed. After that, language knowledge can be changed into application ability to meet the requirement of job, thus promoting cultivation of career-oriented compound talents [1]. Traditional English teaching idea hinders transformation of career-oriented English teaching idea and cultivation of English talents to a large extent. Graduates can adapt to social life after certain training, so it is important to change English teaching idea. The work analyzes transformation of career-oriented English teaching idea.

\section{THEORETICAL BASIS AND NECESSITY OF CAREER-ORIENTED ENGLISH TEACHING IDEA TRANSFORMATION}

\subsection{Theoretical basis of career-oriented English teaching idea transformation}

Competency-based Education (CBE) has been a popular teaching idea and mode for years. Originating from US, CBE is imitated by other countries. It has become theoretical basis of modern education and professional training with development of $\mathrm{CBE}$ theory. CBE can formulate learning target on basis of real job analysis, professional skills and knowledge. Theory of pragmatism, proposed by an American educational expert, criticizes traditional teaching idea and indicates that education is life [2]. Accumulation of knowledge and cultivation of skills should be emphasized in education. Therefore, students can master professional skills and occupation development abilities. Cultivation of English application ability is important in the reform of non exam-oriented education.

\subsection{Necessity of career-oriented English teaching idea transformation}

With the development of world economic integration, science and technology in 21st century, English has been more and more important. Teachers should diversify traditional teaching idea and end the boring time of English teaching. In the past, students mostly learn reading and writing English, ignoring the importance of listening and speaking English in China [3]. Career-oriented English teaching requires students to comprehensively improve English abilities in listening, speaking, reading and writing, thus promoting English application ability and learning interest. In addition, multimedia teaching can be used to motivate students by presenting illustrated teaching content, thus improving students' learning activity and efficiency as well as teachers' teaching quality. 


\section{CAREER-ORIENTED ENGLISH TEACHING SITUATION}

\subsection{Different English levels of students because of enrollment expansion}

Recently, education reform and enrollment expansion result in students with different levels and poorer quality, which has become a great challenge for colleges and teachers. Different students have different abilities. Some have strong learning attitude, weak basis and less vocabulary in English; some consider that English is useless to the job in future and rest easy as long as they pass the examination. They cannot understand the importance of English learning.

\subsection{Lacking scientific and systematic curriculum standard in colleges}

Curriculum standard is the guidance teaching document regulating contents such as curriculum nature, objective, teaching purpose and implementation suggestion. At present, the incomplete curriculum standard set for English teaching cannot describe basic idea, curriculum objective and implementation plan. Actually, it is an empty teaching program. CBE cannot be applied based on non career-oriented curriculum standard. Deficiency of scientific and systematic curriculum standard in colleges hinders development of rational English teaching.

\subsection{Passively receiving knowledge without practice of students}

In career-oriented English teaching mode, students are primary and teachers are assistants. Besides, students should actively participate in class and interact with teachers. However, teachers would rather apply the fixed spoon-feeding teaching idea than new teaching method because of tight lesson and heavy task. In classroom teaching, teachers aim at filling students' brains with knowledge whether they can accept or not, thus restraining activity and interaction between teachers and students. In addition, English teaching content in most of the colleges is to recite words and texts in the book, which limits English ability in listening and speaking as well as career-oriented expansion practice. Therefore, the subject status of students cannot be represented and the learning skills cannot be effectively improved.

\subsection{Lacking career-oriented and targeted teaching materials connecting to reality}

English teaching materials determine teaching quality to a large extent. At present, the old English teaching materials with little application cannot accord with different levels of students in most colleges, thus causing passive and poor learning effect. The teaching materials neglect the importance of application ability to English learning and lack direction of occupation. A good learning habit and method have great influence on learning ability of students. Teachers should carry out teaching based on some extracurricular and online resources.

\section{CAREER-ORIENTED ENGLISH TEACHING IDEA TRANSFORMATION}

\subsection{Motivating students' activities in learning by career-oriented teaching}

Students' activities, motivated by rational factors, can determine effect and application of learning. The purpose of English learning, including examination and communication, can motivate students' activities. Statistics show that $80 \%$ of the students regard English as the key of finding good jobs. Therefore, students can understand the importance of English to their career in future. The importance of English should be emphasized in class. In English teaching, teachers can show the requirements of enterprises. E.g., foreign enterprises require the interviewers to communicate in English. Some interviewers who are proficient in English can obtain a good job in enterprises. By example motivation, students in colleges can work hard. English, as a tool of international communication, is getting more and more important. In curriculum design, students, as the center of teaching, can be guided to apply English knowledge and abilities to teaching activities in the form of task organization.

\subsection{Improving curriculum standard of English teaching}

Teachers should gradually change viewpoint and teaching content. Curriculum standard is one of important standards to train students' position abilities, and teachers should take occupation as the first direction of English teaching. Career-oriented teaching is very important because of different English levels of students. Teachers should aim at improving students' occupation English abilities and qualities rather than learning by rote. Language communication of students should be trained by combining knowledge with social requirements. By understanding the importance of English theory teaching to practice, students can apply knowledge to real life and lay a better foundation for jobs in future. The important factors of curriculum standard should be emphasized, including curriculum nature, objective, teaching content and implementation suggestion. Rational difficulty, length and career- 
oriented content of teaching materials should be comprehensively considered based on talent market requirements and different English levels of students.

\subsection{Improving students' English abilities in listening and speaking rather than reading and writing}

Teachers should urge students to train their listening and speaking abilities and listen to English materials after class. Some interesting English movies and webs can be introduced to students. The students should keep listening without understanding the meaning of materials. The key of English learning is to study hard and cultivate language sense for application. Interaction with foreign teachers is also a good way of improving English. Students can find the method of English learning in listening and speaking by using solid language basis.

English listening contains understanding of words and sentences. Students should master the key words and the whole content of listening materials including relation between sentences. In traditional teaching, students are required to remember enough words. However, in order to apply language to communication, more reading, writing, listening and practice should be emphasized in language learning. Teachers can train students' language abilities by simulation of professional environment. In traditional teaching, teachers initiate students into content of teaching program. However, in career-oriented English teaching, teachers should introduce diversified methods including short sentence performance and topic discussion, thus creating an opportunity of practice and finishing dummy English. The common subjects at workplace are divided into different modules such as ordering, interview and business negotiation in English. Data collection and task execution can improve students' English application abilities. By extracurricular teaching activities such as guidance for foreigners in scenic spot, students can participate in English communication. Therefore, students can be familiar with working fields and easily find jobs in future.

\section{CONCLUSIONS}

The purpose of modern English education is to develop more application talents rather than bookworms to meet requirements of modern society. English teaching idea should be transformed to motivate students' interest and passion based on requirements of workplaces in future and students' English levels. Students can remain invincible in the coming career by scene simulation and ability training, thus achieving learning for practice and improving comprehensive abilities in learning.

\section{REFERENCES}

[1] Feng Haiyan, Career-oriented English Teaching Reform in Higher Vocational Colleges, New West, 2012(8): 173.

[2] Zheng Yangmei, Audiolingual-visual and Practice Teaching Reform of Career-oriented Vocational English, Examination Week, 2013(5): 11.

[3] Min Jianjie, Confusion and Outlet of Higher Vocational English Teaching, The Guide of Science and Education, 2007(2): 56. 